\title{
RESOURCE SAVING TECHNOLOGIES IN THE CULTIVATION OF SECOND CROPS
}

\author{
Chingizkhon Vali ugli Toshpulatov \\ Assistant of the Department of Farming and Land Reclamation, Tashkent State Agrarian University, \\ Tashkent, Uzbekistan
}

Botir Burievich Tukhtashev

Candidate of Agricultural Sciences, Docent of the Department of Farming and Land Reclamation, Tashkent State Agrarian University, Tashkent, Uzbekistan

Mekhriban Koylibaebna Ajiniyazova

Assistant of the Department Farming, Selection and Seed Breeding of Agricultural Crops, Nukus branch of Tashkent State Agrarian University, Nukus, Karakalpakstan, Uzbekistan

\section{Umrzok Lapasovich Gaziev}

Assistant of the Department Soil Science, Gulistan State University, Gulistan, Uzbekistan

\begin{abstract}
The expenses related to the agricultural production include the application of fuel and lubricants, high quality seeds, fertilizers and various pesticides, high-performance machinery and mechanisms, the deterioration of land reclamation and increasing costs of salinization and erosion, irrigation and other production now require diversified demand for its production.

Based on this requirement, the crop received by non-conventional methods of land cultivation and raising double crops, the harvest of 17.0 c/ha was mung bean, 24.7 c/ha made up beans and corn constituted 46.2 c/ha.
\end{abstract}

KEYWORDS: Surface treatment, second crop, irrigation, resource-saving, method, soil, non-conventional tillage, technology, variant, plough, harrow, surface tillage.

\section{INTRODUCTION}

The expenses related to the agricultural production include the application of fuel and lubricants, high quality seeds, fertilizers and various pesticides, highperformance machinery and mechanisms, the deterioration of land reclamation and increasing costs of salinization and erosion, irrigation and other production now require diversified demand for its production.

Based on this requirement, each technology must be considered in terms of energy saving, i.e. the output of the product is low cost $[1,2]$.

Introduction of non-conventional methods in the farming practice is a critical issue in the preparation of winter freed fields for cultivation of second crops.
In this regard, it is not mistake to say that the reforms, which are aimed at improving the quality of living standard of the population of the country will be effective in the short term.

The use of resource-saving advanced technology to produce high-quality, competitive products from field crops is one of the most important tasks.

The significance of resource-saving technology is that every three or four years, the soil is thoroughly cultivated, and the following years it is used with surface treatment equipment.

In this process, the soil is not compacted, microflora does not deteriorate, soil particles are not powdered and most importantly, porosity, density, retention, air, grain and other parameters are well preserved $[3,4]$. 


\section{EPRA International Journal of Research and Development (IJRD)}

In order to reduce the cost of production, it is necessary to introduce a resource- saving technology of tillage, including planting in stubble land.

The benefits of introducing this technology are: the cost of fuel and lubricants is halved; water consumption is reduced by $30 \%$; seeds can be sown in short time [3, 4].

\section{MATERIALS AND METHODS}

Research conducting method. For field experiment the winter wheat freed area was selected. First, the residue of straw is harvested. For this purpose straws are organized into small groups.

The soil loosened to a depth of $12-15 \mathrm{~cm}$ by using existing surface devices -cultivators (KPX-4) or chisel cultivator (KPN-4A)

After the seed has been sown, the irrigation furrows are uncovered. Field experiments were conducted with the following options;

\section{Variants. Types of crop.}

1. Usual tillage of the land (plough + harrowing) + mung bean;

2. Usual tillage of the land (plough + harrowing) + haricot bean (red);

3. Usual tillage of the land (plough+harrowing) + corn;

4. Non-conventional tillage (chisel cultivation) + mung bean;

5. Non-conventional tillage (chisel cultivation) + haricot bean (red);

6. Non-conventional tillage (chisel cultivation) + corn.

The following calculations were made in the experiment: volume of soil is determined by sampling the soil with no disturbed state.

Soil water retention is determined by the method of soaking in 6 hours developed by UzCGSRI. The soil moisture content is measured by drying at a thermostat before and after each irrigation.

The amount of the field water is calculated using Chipoletti (BCh-25) and Thomson (VT-90) water meters.

The date of the second crop sowing was recorded; -grass production - begins to sprout; germination time; budding - beginning and ending time; -flowering - the beginning time and bloom time; -maturation- beginning and completed time; -days passed before fully matured; - weight of 1000 pcs of seeds were calculated;

After harvesting, approximately $25-50$ pcs of plants at the same size and thickness from different areas of the field were harvested and milled, then the seeds were weighed.

The weight of the seed is divided by the number of the obtained plants so that the yield of one plant is determined.

The total yield on the experimental field was calculated as follows: The number of plants per unit area, number of plants per plant, number of legumes and by calculating weight of 1000 pcs of seeds were determined.

Planting of double crop. Field experiments were conducted in 3 repetitions in 6 variants. The width of the experimental field was $43.2 \mathrm{~m}$, the height was $50 \mathrm{~m}$, the total area constituted $2160 \mathrm{~m}^{2}$ or $21.6 \mathrm{sq} . \mathrm{m}$. The surface of one plot was $120 \mathrm{~m}^{2}$ with an area of 60 $\mathrm{m}^{2}$. Each plot is equal to one sidewalk. Experimental variants were placed in one circle. The total number of rows was 72 when 3 repetitions were repeated in 6 variants.

1. When mung bean was planted in $60 \times 10$ schemes 166,666 mounds per hectare were produced and $14 \mathrm{~kg}$ of seeds was spent.

2. When sowing beans (red) $60 \times 15$ schemes, 111.111 mounds per 1 ha were produced $22-25 \mathrm{~kg}$ seeds was spent.

3. The corn was also planted in a $60 \times 15$ schemes and $22-25 \mathrm{~kg}$ per hectare was used.

\section{RESULTS AND DISCUSSION}

Gaining high and quality grain form double crop depends on the agrotechnics of its cultivation. In the plant growth under the optimal conditions and provides all the conditions for its growth, it grows well and produces high yield. The normal implementation of agro- technical measures used in plant growing determines the entry of crops to the development stages in optimal terms.

The pulses go through the following key stages in the development of grain crops. They are greenness, ramification, budding, and maturing of the grain.

We studied from the phenological observations that they are correctly identifying the stages of growth of reproductive crops.

Specifically, the newly planted crops sprouted early, i.e. mung bean sprouted on 20.06, and the bean sprouted on 30.06 .

The corn sprouted on 4.07 which was planted at he same time with these pulses. After sown double crop $500-600 \mathrm{~m}^{3} /$ ha seed water per hectare was given.

Adequate soil temperature and proper agricultural practices had a positive effect on their transfer to phenological phases.

In particular, it is not wrong to say that each crop entered the ramification phase at the same time. If the mung been enters the ramification phase on July 25 , the beans enter this phase after July 27 and that was 36 days after sowing.

It takes 7-10 days for leguminous plants to complete ramification phase. In this case, the mung bean was enough for 38 days and 40 days for beans.

The legumes planted as a second crop after winter wheat - the rows of mung bean and beans were lightly cultivated in order to be clear. Before the tillage of the soil the land was treated with $40-60 \mathrm{~kg}$. of phosphorus and $20-40 \mathrm{~kg}$ of potassium per hectare. During the 
budding and flowering stages $20-30 \mathrm{~kg}$ of phosphorus and $10-20 \mathrm{~kg}$ of potassium were added. The next phase of the development of all pulses began early. Specifically, the mung bean entered the flowering phase 35 days after sowing and this indicated 40 days later in beans. The corn planted as a second crop entered the flowering phase 66 days after sowing. In the legumes planted as a secondary crop, the maturity of the grain was slightly delayed. As temperatures fall by the end of September, the process of grain maturation was slower. In the experiment, $85-90 \%$ of the crops sown as secondsry crop ripened, including the mung bean and maize in 90 days, the beans harvested in 107 days respectively. It shoul be noted that the temperature of late September and October are important in the cultivation of second crops. Accordingly, double crop vegetaion can also reduced as well as delayed. The early precipitation also impact on this. The mung beans legumes are not as long as ripening period, but the lower part of the leaves on the bottom of the stem begin to fall and to turn yellow. The mung bean can be harvested after $70-75 \%$ ripening.

The lower leaves of the beans begin to turn yellow and begin to be harvested when the legumes reach $60 \%$. Otherwise, the lower part of the harvest opens and falls on the ground.
In non- conventional methods, such as surface treatment devices, the rotation period was 87-90 days and the yields were harvested in early October. There was no significance difference in harvest technology in both methods.

However, it should be noted that under conventional technology, second crop yields are not fully matured due to slightly lower and rainy late autumn.

This was especially observed in beans and corn. In particular, in the conventional methods of cultivation of land - $15.2 \mathrm{~kg} / \mathrm{ha}$ mung bean, $20.2 \mathrm{c} /$ ha beans, $43.2 \mathrm{c} / \mathrm{ha}$ corn were produced, while in non-conventional method these indicates were for mung bean $17.0 \mathrm{c} / \mathrm{ha}$, for bean $24.7 \mathrm{c} /$ ha and for corn it was $46.2 \mathrm{c} /$ ha (Table).

It should be noted, that the fallow period id delayed due to the delay in harvesting the second crops in conventional options of land prepared.

In the non- conventional way, that is the options for the timely cultivation of the winter plow are fully preserved, with the option of using surface tillage tools, which allows the timely sowing of winter wheat. We believe that it will be important for our farmers to use this land properly.

Table

Productivity of second crops, c/ha

\begin{tabular}{|l|l|c|c|c|c|}
\hline \multirow{2}{*}{ № } & \multicolumn{1}{|c|}{ Variants } & \multicolumn{3}{c|}{ Repetitions } & Total productivity, \\
c & & I & II & III & \\
\hline 1. & Mung bean (conventional fallow method) & 15,7 & 15.1 & 14,4 & 15,2 \\
\hline 2. & Bean (conventional fallow method) & 20,1 & 20.5 & 19.8 & 20,2 \\
\hline 3. & Corn (conventional fallow method) & 42,7 & 43.0 & 44,1 & 43,2 \\
\hline 4. & Mung bean (non-conventional method) & 17,7 & 16.6 & 16,7 & 17,0 \\
\hline 5. & Bean (non-conventional method) & 25,1 & 24,8 & 24.3 & 24,7 \\
\hline 6. & Corn (non-conventional method) & 45,4 & 46.6 & 46,4 & 46,2 \\
\hline
\end{tabular}

\section{CONCLUSION}

In the cultivation of second crops, it is important to note that, in the conventional variants soil preparation, the fallow period is delayed due to the delay in harvesting the second crops.

In the non-conventional way that is the option for timely cultivation of the winter plough will be fully performed, with the option of using surface tillage tools and will allow the timely sowing of winter wheat. We believe that it will be critical for our farmers to apply this land properly.

\section{REFERENCES}

1. Atabaeva KH., Umarov Z.U., Buriev Kh.Ch. (2000). "Plant science", Tashkent «Mehnat», pp. 18-30. (in Uzbek)

2. Dospekhov B.A. Б.A. (1985). Methods of field experience. Moscow, "Kolos», 354 p. (in Russian)

3. Kholikov B., Buriev Ya., Buriev T. Бурриев T. (2007). Agrophysical properties of soil in crop rotation.
International Scientific and Practical conference of materials collection on the subject To increase soil fertility of UzCGSRI, Tashkent, pp. 141-142. (in Uzbek)

4. Tukhtashev B.B., Sultonov U.S. (2018). Basis of second crops sowing without plowing. Tashkent, pp. 37-39. (in Uzbek) 